\title{
多円形断面シールドの掘削特性に関する実験的研究
}

\section{AN EXPERIMENTAL STUDY OF MULTI-CIRCULAR FACE SHIELD TUNNELLING}

\author{
松 本 嘉司*・新 井 時 夫**・波多腰 明*** \\ By Yoshiji MATSUMOTO, Tokio ARAI and Akira HATAKOSHI
}

\begin{abstract}
Using an ordinary circular shield for construction of double track railway tunnel, the cross section becomes larger than the net required section. As a result, the construction work takes not only more cost but also longer time. The multi-circular face (MF) shield tunnelling has been developed to mitigate these problems, and can build a tunnel with a special cross section comprising multi-circles partially overlapped.

In this study, the experiment is executed to make clear the basic behaviors of doublecircular face shields (one with two faces aligned horizontally and the other with faces aligned vertically). The results show that the cutter torque and total thrust force of the MF shield are smaller than those of a circular face shield to construct the same double track railway, and that the MF shield has good characteristics in the stability of a cutting face and in its maneuverability.

Keywords: multi-circular face, shield tunnelling, experimental study
\end{abstract}

\section{1. まえがき}

多円形断面シールドトンネル（MFS）工法は複数の 円形断面を一部重ね合わせて掘削するトンネル施工法 ${ }^{11}$ であり，今後の地下空間の有効利用に大きな役割を果た していくものと考えられる．図一1 は複線鉄道用の円形 シールドトンネルと複円の横型 MF シールドトンネル との断面を比較して示したものである.このように断面 を多円形型にすると，掘削断面積が少なくなり経済的に なる。また，トンネル内の換気にも有利な構造と考えら れる (表一 1 参照). JR 東日本京葉都心線京橋シールド トンネルは，この工法を用いて施工されたものであり， そこでの設計および施工実績については，著者はすでに 先の論文 ${ }^{2)} ゙$ 発表した. また，その論文で横型 MFS 工 法の応用として縦型 MFS 工法について示したが, 縦型 MFS 工法は，地上部占有面積が少なくて済むことから， 用地制限の厳しい地域では, 今後需要が発生してくるも のと考えられる. しかし，これらの MF シールドは,

* 正会員 工博 東京大学教授 工学部土木工学科 (テ113 文京区本郷 7-3-1)

** 正会員 株式会社 熊谷組 東京支店 支店次長 (テ162 新宿区筑土八幡町 3-1)

*** 三菱重工業株式会社 神戸造船所 建機設計課長 （６52 神戸市兵庫区和田崎町 1-1-1)

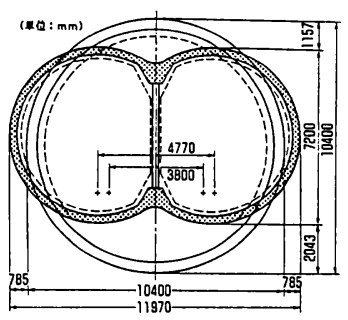

図一1断面比較

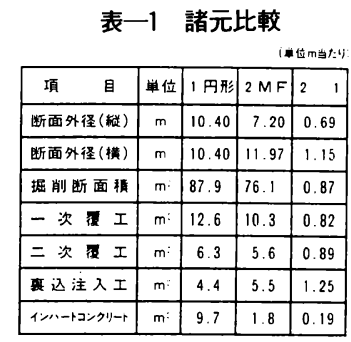

従来の円形断面のシールドに比べ特殊な断面形状である ため技術的問題点も多く，シールドの設計方法，掘削時 の姿勢制御方法など確立されていないところが少なくな w.

本研究は, 従来の円形断面シールドと複円の横型およ び縦型 MF シールドの掘削特性を模型実験により解明 し, MF シールドの特性について考察したものである.

\section{2. 実 験 概 要 ${ }^{3), 4)}$}

\section{（1）実験の目的}

実験は，広範囲な地質への対応が可能で切羽安定性に 優れた面板形の密閉型泥水式シールドを対象とした。ま た， MF シールドのカッターヘッド配列には同一平面 
表一2 MF シールドにおける解明すべき現象

\begin{tabular}{|c|c|c|c|}
\hline & 円形シールトとの相息点 & & 工時の具体的現象 \\
\hline \multirow{2}{*}{$\begin{array}{l}\text { 横 } \\
\text { 型 } \\
\text { M } \\
\text { F }\end{array}$} & 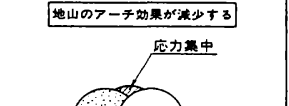 & $\begin{array}{l}\text { 篦 } \\
\text { 制 } \\
\text { 御 } \\
\text { 性 }\end{array}$ & 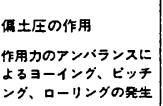 \\
\hline & 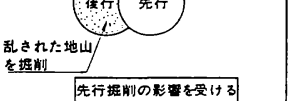 & $\begin{array}{l}\text { 切 } \\
\text { 羽 } \\
\text { 安 } \\
\text { 定 } \\
\text { 性 } \\
\end{array}$ & 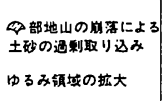 \\
\hline \multirow{2}{*}{$\begin{array}{l}\frac{5}{\text { 部 }} \\
\text { 先 } \\
\text { 行 } \\
\text { 筑 } \\
\frac{\text { 型 }}{M} \\
F\end{array}$} & 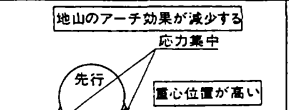 & $\mid \begin{array}{c}\text { 等 } \\
\text { 制 } \\
\text { 御 } \\
\text { 性 }\end{array}$ & 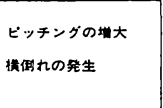 \\
\hline & 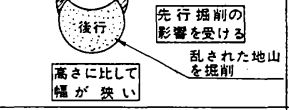 & $\begin{array}{l}\text { 切 } \\
\text { 羽 } \\
\text { 定 } \\
\text { 性 } \\
\end{array}$ & 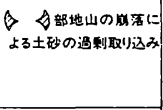 \\
\hline \multirow{2}{*}{$\begin{array}{l}F \\
\text { 部 } \\
\text { 先 } \\
\text { 行 } \\
\text { 綎 } \\
\frac{\text { N }}{M} \\
F\end{array}$} & 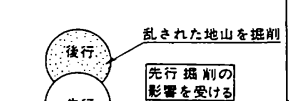 & 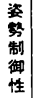 & 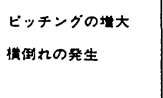 \\
\hline & 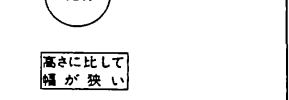 & \begin{tabular}{|l} 
切 \\
羽 \\
安 \\
定 \\
性
\end{tabular} & 由ろ み锁域の拉大 \\
\hline
\end{tabular}

で同期回転を行うものも考えられるが1)，機動性を重視 しそれぞれの独立回転が可能なようにカッターを前後に ずらした構造のものを実験対象とした.

ところで， MF シールドはその形状が円形シールド に比べ特殊であるだけでなく複数のカッターが掘削時に 相互干渉する可能性があり，ゆるみ土圧，カッタートル ク，推進力，不つり合い力などが増大することも考えら れる. 表一2 は本実験の対象である複円の MF シール ドについて解明すべき現象を示したものである.そこで, これらの現象が掘進条件や地盤条件などによって複線鉄 道用の円形シールドとどのような差異がでるのかを解明 し，MF シールドの実用化を図るために模型実験を実 施した。なお，実験は，円形シールド，複円の横型およ び縦型 MF シールドについて行った。

\section{（2）実験装置（図一2 参照）}

実験装置は, シールド，土槽，移動架台，カッター軸 駆動装置, 推進装置, 排土装置, 油圧ユニット, 制御盤, および一連の計測システムから構成される. シールドは, それを支持している移動架台が油圧シリンダーにより前 進することにより，土槽中を直進する．カッタ一の形式 は，泥水シールドを念頭に置き面板式としたが，排土方 法は，装置製作上の問題から泥水式とせず，チャンバー 内の土砂をスクリューコンベアにより排出する方法とし た．また，MF シールドの 2 つのカッターは， 2 台の油 圧モー夕により独立に任意の回転方向および回転速度で 駆動できる.

模型寸法は，それぞれ実際の複線鉄道用のシールドを 想定し，幾何学的縮尺が同一となるように決定した。な お，ビット高さ，面板開口率，ビット配置，チャンバー 形状は，模型を小型のシールドとみなして決定した。ま た, 縦型 MF シールドでは, 上部カッター,下部カッター のいずれを先行させるかは，切羽安定性に関する数值解 析によっても両者の差は顕著でなく ${ }^{5}$ 明確な評価ができ ないため, 実験は上部先行型および下部先行型について 行った.

\section{（3）実験条件}

実験地盤は，地盤強度が実験結果に及ぼす影響をみる

表一3 地盤条件

\begin{tabular}{|c|c|c|}
\hline & 軟地盤 & 硬地盤 \\
\hline 湿閵密度 $r^{t}\left(\mathrm{gf}^{\prime} / \mathrm{cm}^{3}\right)$ & $1.56 \sim 1.61$ & $1.68 \sim 1.77$ \\
\hline 䡎燥密度 $\quad r d\left(\mathrm{~g}^{\left.\mathrm{f} / \mathrm{cm}^{3}\right)}\right.$ & $1.42 \sim 1.46$ & $1.56 \sim 1.60$ \\
\hline 含水 比 $w$ & $10.0 \sim 11.2$ & $7.7 \sim 10.9$ \\
\hline 間隙比 $\mathrm{e}$ & $0.80 \sim 0.86$ & $0.65 \sim 0.71$ \\
\hline 飽和度 $\mathrm{Sr}$ & $31.1 \sim 35.9$ & $29.2 \sim 44.0$ \\
\hline 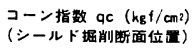 & $10 \sim 30$ & $100 \sim 130$ \\
\hline
\end{tabular}

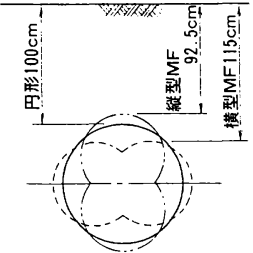

図一3 土被りの比較

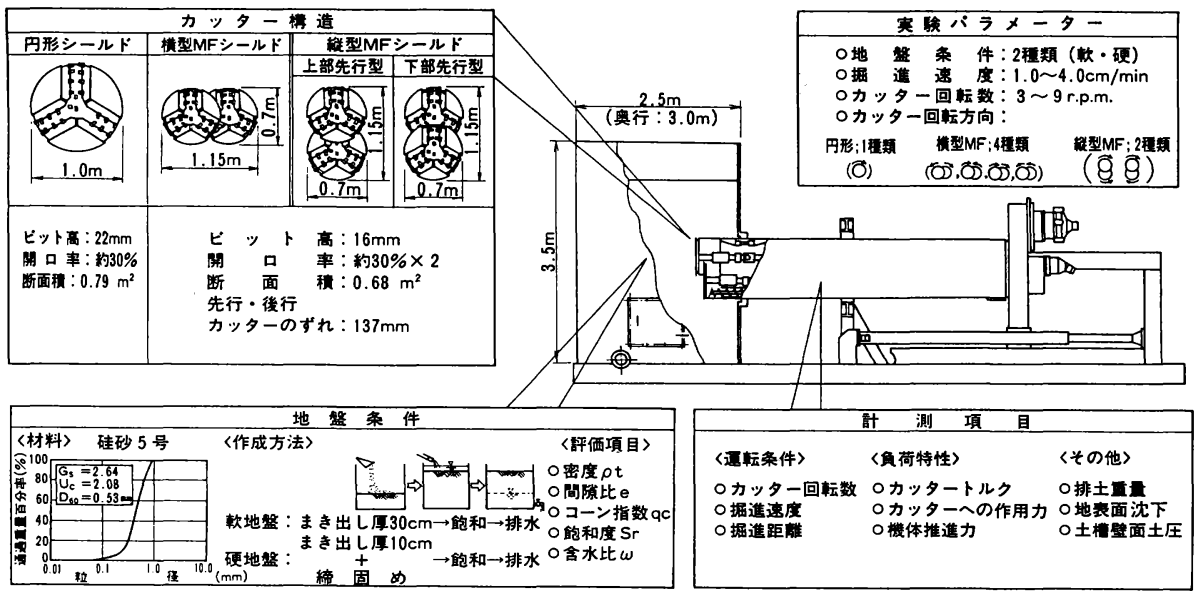

図一2 実験概要図 
模型実呀(円形シールド) 模型実験(MFシールト)

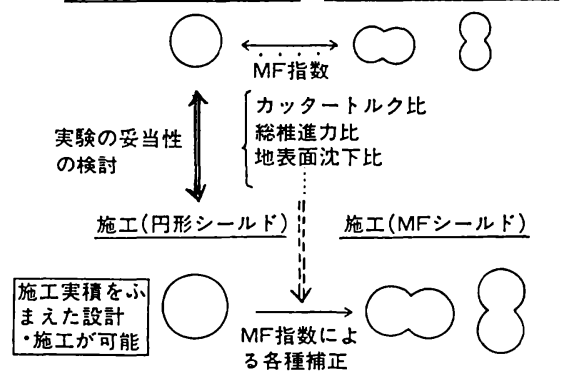

図一4実験結果の評価法

ため, 表一 3 に示す 2 種類とした。また，土被りは，図 一3に示すように円形シールドを $100 \mathrm{~cm}(=1 D: D$ は シールド外径) とし，MF シールドについては，中心 高さを円形シールドに一致させた。

カッター回転数および掘進速度は実験要因とし, それ ぞれ一般のシールドのカッター外周速度, 掘進速度を参 考にして，その範囲を設定した。 カッタ一回転方向も実 験要因とし，図一2に示す組合せとした。

\section{（4）実験の評価方法}

地盤〜機械系の模型実験では，相似則をすべてにわ たって撖密に満足することは困難である，そこで，実験 結果の評価は図一4に示す考え方を用いた。すななち， 円形シールドのカッタートルクなどの実験結果を施工実 績と比較することで，まず，実験の妥当性を確認した。 次に, MF シールドと円形シールドの実験結果を比較し, カッタートルク, 推進力などについて両者の比 (MF 指 数) を求めることで MF シールドの特性を評価した.

\section{3. 実験結果}

\section{（1）負荷特性}

\section{a) カッタートルク}

カッタートルクの計測はカッター駆動モータの油圧を 測定することによって行った。図一5，6におのおのの シールドにおけるカッタートルク $T$ を，それぞれ軟地 盤，硬地盤について示す。なお，MF シールドの $T$ は 先行と後行のカッタートルクの和 (総カッタートルク) である. カッタートルクは掘進条件（掘進速度 $V$, カッ 夕一回転数 $f)$ による影響を受け, $V / f$ との間に線形 相関性が認められた. 特に硬地盤においては相関係数が 大きい.また, カッタートルクの大きさは, 硬地盤と軟 地盤とで大差はなかった.

$\mathrm{MF}$ シールドのカッタートルクは, シールド型式に よらず円形シールドの $50 \%$ 以下であった。 また, 綐型 $\mathrm{MF}$ シールドのカッタートルクは横型 MF シールドの 40〜60\%であった。

縦型 MF シールドの場合, 上下のチャンバーに隔壁

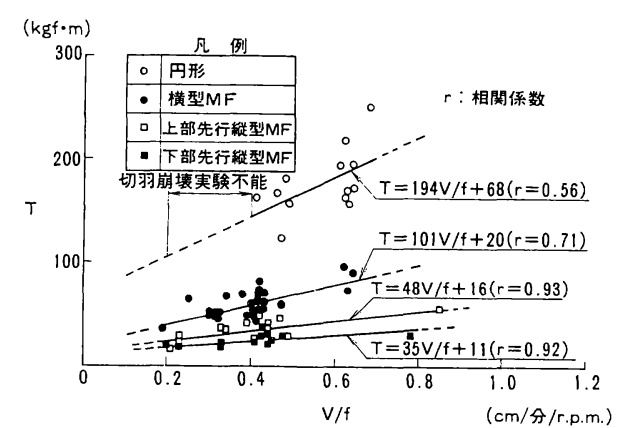

図一5 $T$ と $V / f$ の関係 (軟地盤)

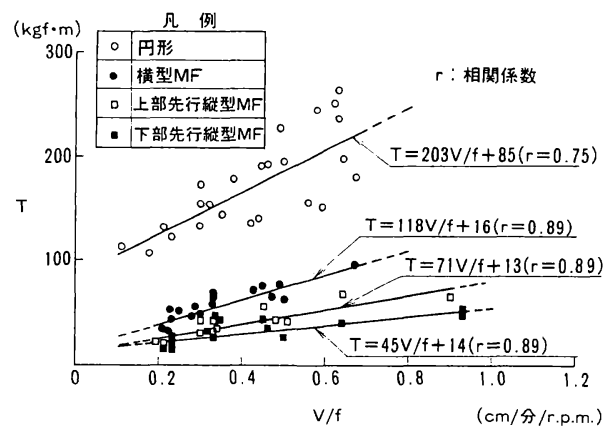

図一6 $T$ と $V / f$ の関係 (硬地盤)

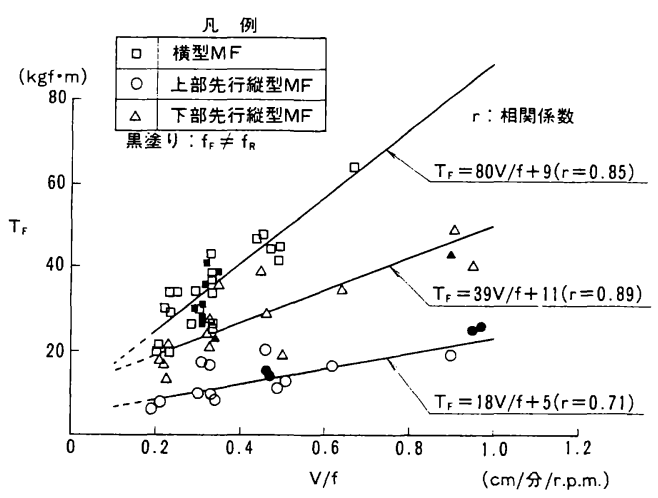

図一7 $T_{F}$ と $V / f$ の関係

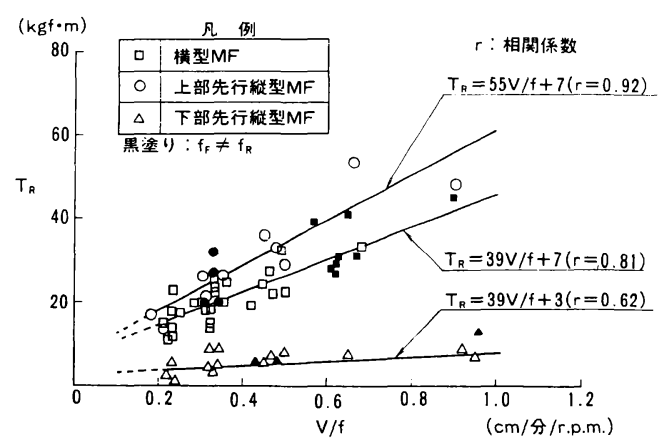

図一8 $T_{R}$ と $V / f$ の関係 
のない構造としたため, 上部カッターのチャンバーは， 土砂の充填度が低く土砂の取込みが容易である．このた め, カッタートルクが小さくなったものと推察できる. また，チャンバーに隔壁のある構造とした場合の縦型 $\mathrm{MF}$ シールドのカッタートルクを推定するために, 上 部カッターと掘削面積が等しい下部カッターのカッター トルクを上部カッタートルクとした。すすなち，上部先 行型では下部先行型の, 下部先行型では上部先行型の下 部カッタートルクをそれぞれの型式における上部カッ タートルクとし, 総カッタートルクを求めてみたが, 横 型 MF シールドの 80〜90\% であった.

図一7, 8 に $\mathrm{MF}$ シールドの先行カッタートルク $T_{F}$, 後行カッタートルク $T_{R}$ を示す. 図には, 種々のカッター 回転方向に対する結果を同一の記号でプロットしてある が，データはばらつかず， $T_{F}$ および $T_{R}$ と $V / f$ の間に はそれぞれ線形の相関性が認められる. また，先行カッ 夕一の回転数 $f_{F}$ 亡後行カッターの回転数 $f_{R}$ に差を与え た場合 $\left(f_{F} / f_{R}=0.33 \sim 3.0\right)$ も，この相関関係を満足し ている.これらより, $\mathrm{MF}$ シールドの両カッターは, 他のカッターの回転方向や回転数に依存することのない 独立の特性をもつことが確認された.

\section{b ) 機体推進力}

シールドの掘進に対して抵抗する主な力は, 切羽前面 抵抗力 $F_{t}$ および周面摩擦抵抗力 $F_{f}$ である.

$F_{t}$ は, カッター軸のひずみ計によりカッタ一軸力と して測定した．図一9は， $F_{t}$ と $V / f$ との関係を示した ものである. 横型および縦型 $\mathrm{MF}$ シールドの $F_{t}$ は円形 シールドの 50 ～60\% である. なお，同図に $F_{t}$ と $V / f$ の直線回帰式を示したが, MF シールドはデータにシー

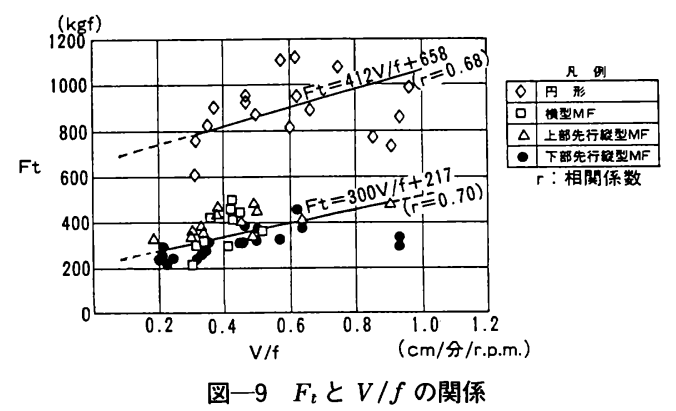

表一4 $\quad F_{f}$ 計算結果

\begin{tabular}{|c|c|c|c|c|c|c|}
\hline シー & \multirow{2}{*}{ 円 形 } & \multirow{2}{*}{ 拱型MF } & \multicolumn{2}{|c|}{ 柣型 M F } & \multirow{2}{*}{ 墸 } & \multirow{2}{*}{ 考 } \\
\hline 項 & & & 上部先行型 & 下部先行型 & & \\
\hline 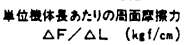 & 24.9 & 23.3 & 17.6 & 19.3 & $L$ & MFシー \\
\hline$(\mathrm{cm})$ & 314 & 318 & 318 & 318 & & 体長 L \\
\hline 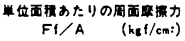 & 0.079 & 0.073 & 0.055 & 0.061 & 体畏L & W+nt \\
\hline 周国㨲抵抗力 $\mathrm{Ff}(\mathrm{kg} f)$ & 2.120 & 1.880 & 1.420 & 1,560 & & \\
\hline
\end{tabular}

ルド型式別の有意差が認められなかったため全データを 用いて求めた。

$F_{f}$ は，表一4のようにして求めた。 まず，推進ジャ キの油圧により測定した総推進力 $F$ が, 掘進距離 $L$ の 増加に対してどの程度の割合で増加するかを求めた。こ の増加率 $\Delta F / \Delta L$ が単位機体長当たりの周面摩擦力で あり, 次に, これをスキンプレートの周長で除して, ス キンプレートの単位面積当たりの周面摩擦力 $F_{s} / A$ を求 め, 最後に, スキンプレートの面積（シールド機体長を いずれも $85 \mathrm{~cm}$ として算定）を $F_{f} / A$ に乗じて, $F_{f}$ と した. $F_{f}$ の大小関係は円形シールド>横型 $\mathrm{MF}$ シール ド>縦型 MF シールドとなり，また，縦型 $\mathrm{MF}$ シール ドにおいては, 下部先行型の方がやや大きい.

c ) カッター軸力およびカッターせん断合力

カッターに作用する力は, 図一10に示すような軸力 (面外荷重) とせん断力（面内荷重）である. 実験では, カッター軸のひずみ計により，カッタ一軸の軸力 $N$ と 曲げモーメント $M$ を計测した。なお， $M$ を図一11に 示すように, $N$ の作用位置の偏心による成分 $M_{N}$ とせん 断力の合力 $S$ による成分 $M_{S}$ に分解し, $M_{S}$ から力ッ夕ー せん断合力 $S$ を求めた。

図一12 は, 円形シールドおよび MF シールドの先行

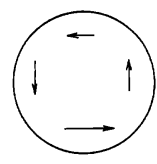

〈せん断力〉

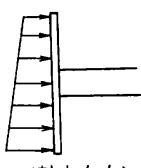

〈軸方向力〉

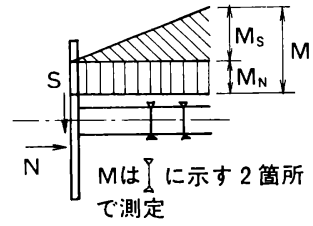

図-11 $M$ の成分
図一10 カッターに作用するカ

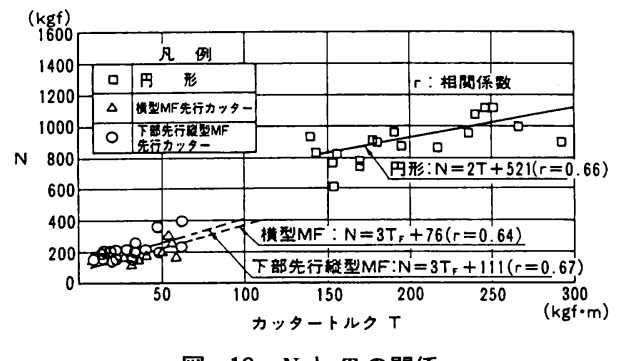

図-12 $N$ と $T$ の関係

表一5 $N$ 回帰結果

\begin{tabular}{|c|c|c|c|}
\hline \multicolumn{2}{|c|}{ シールド型式 } & 回 龽 式 & 相関係数 \\
\hline 円 & 形 & $N=2|T|+521$ & 0.66 \\
\hline \multirow{2}{*}{ 栱型MF } & 先行カッター & $N=3\left|T_{F}\right|+76$ & 0.64 \\
\hline & 後行カッター & $N=7\left|T_{R}\right|-14$ & 0.74 \\
\hline \multirow{2}{*}{$\begin{array}{l}\text { 上部先行 } \\
\text { 型MF }\end{array}$} & 先行カッター & $N=6\left|T_{F}\right|+52$ & 0.68 \\
\hline & 後行カッター & $N=4\left|T_{R}\right|+142$ & 0.95 \\
\hline \multirow{2}{*}{$\begin{array}{l}\text { 下部先行 } \\
\text { 橔型MF }\end{array}$} & 先行カッター & $N=3\left|T_{F}\right|+|| \mid$ & 0.67 \\
\hline & 麸行カッター & $N=8\left|T_{R}\right|+51$ & 0.70 \\
\hline
\end{tabular}




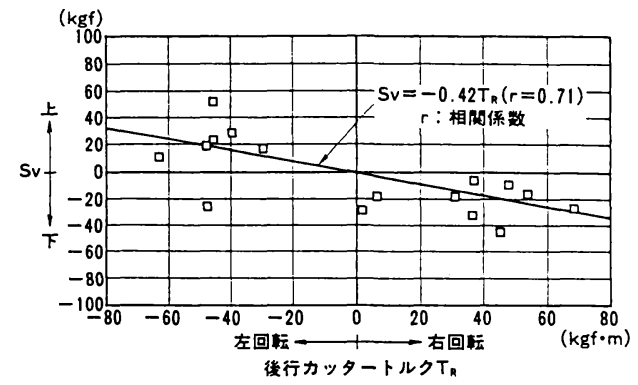

図-13 $S_{V}$ と $T_{R}$ の関係 (横型 $\mathrm{MF}$ シールド)

表一6 発生せん断合力の推察

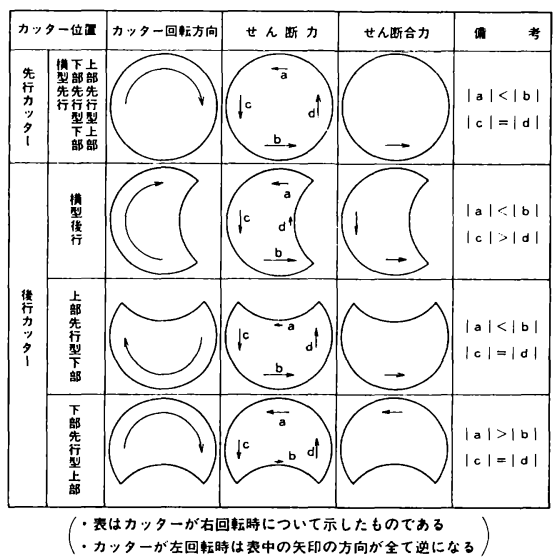

カッターの軸力 $N$ とカッタートルクとの関係を示した もので, それぞれ正の相関性が認められた.この傾向は, 他のカッターについても同様であり，Nと $T$ の直線回 帰式をまとめると，表一 5 となる.

カッターせん断合力 $S$ の鉛直方向成分 $S_{v}$, 水平方向 成分 $S_{H}$ は, それぞれ, カッターに作用する鉛直方向, 水平方向のせん断力の不つり合いを表わすものである. $S_{V}$ は, 横型 $\mathrm{MF}$ シールドの後行カッターを除いていず れも小さな值であった.これは, カッタ一の形状が左右 対称のため, 鉛直方向のせん断力が左右でつり合ってい るためであると考えられる. 横型 $\mathrm{MF}$ シールドの後行 カッターの $S_{V}$ は, カッタートルクとの間に図一13に示 すような関係があり, カッターが右回転時に下方向, 左 回転時に上方向の $S_{\boldsymbol{V}}$ が作用していた.この鉛直方向の せん断力の不つり合いは, 表一6で推察するように先行 と後行の面板が重なっていることによって生じたものと 考えられる.

一方， $S_{H}$ は, 縦型でも横型でもすべてのシールドの カッターで生じた. 縦型 $\mathrm{MF}$ シールドにおける $S_{H}$ と カッタートルクとの関係を図一14に示す. いずれのカッ ターについても両者には強い相関関係がある.このこと は, 他のシールドのカッターについても同様であり, 表

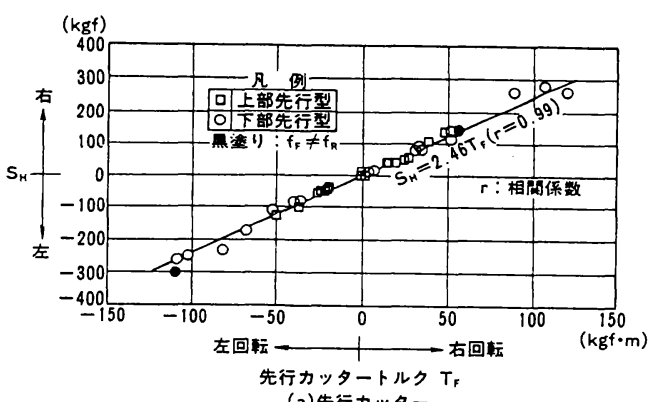

(a)先行カッター

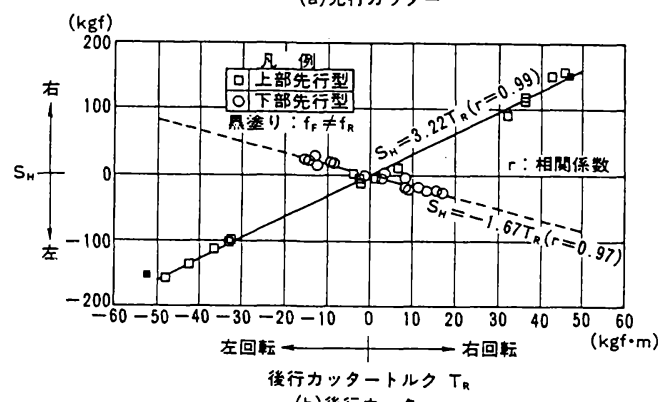

(b) 啳行カッター

図一14 $S_{H}$ と $T$ の関係 (縦型 $\mathrm{MF}$ シールド)

表一 $\quad S_{H}$ 回帰結果

\begin{tabular}{|c|c|c|c|}
\hline \multicolumn{2}{|c|}{ シールト型式 } & 回 帰 式 & 相関係数 \\
\hline \multicolumn{2}{|l|}{ 丹 } & $\mathrm{S}_{\mathrm{H}}=1.71 \mathrm{~T}$ & 0.96 \\
\hline \multirow{2}{*}{ 横型M F } & 先行カッター & $S_{H}=2.40 \mathrm{~T}$ & 0.96 \\
\hline & 後行カッター & $\mathrm{S}_{\mathrm{r}}=1.80 \mathrm{TF}_{\mathrm{F}}$ & 0.98 \\
\hline \multirow{2}{*}{$\begin{array}{l}\text { 上部先行 } \\
\text { 綐型M F }\end{array}$} & 先行カッター & $\mathrm{S}_{\sim}=2.46 \mathrm{~T}=$ & 0.99 \\
\hline & 後行カッター & $S_{n}=3.22 T_{R}$ & 0.99 \\
\hline \multirow{2}{*}{$\begin{array}{l}\text { 下部先行 } \\
\text { 縦型MF }\end{array}$} & 先行カッター & $S_{U}=2.46 \mathrm{Tr}$ & 0.99 \\
\hline & 後行カッター & $\mathrm{S}=-1.67 \mathrm{~T}_{\mathrm{R}}$ & 0.97 \\
\hline
\end{tabular}

一7は $S_{H}$ とカッタートルクの直線回帰式をまとめたも のである. $S_{H}$ は, 下部先行縦型 $\mathrm{MF}$ シールドの後行カッ ターを除き, カッターが右回転時に右方向, 左回転時に 左方向となった. 形状が上下対称のカッターにも， $S_{H}$ すなわちせん断力の水平方向の不つり合いが生ずるの は, カッター前面土圧が梁さ方向に増加するためである と考えられる.なお, MF シールドの先行カッターでは, $S_{\mathrm{H}}$ とカッタートルクとの関係式における傾きが 2.40 2.46 とほぼ同じである．これは，土圧分布形状が互い に相似であるためと考えられる. また, 上部先行縦型 $\mathrm{MF}$ シールドの後行カッターでは傾きが 3.22 と大きく, 下部先行型の後行カッターでは傾きが負となるが，これ は先行カッターと重なる部分の後行カッターにせん断力 が発生しないことによるものと考えられる（表一6参 照).

図一14に, 先行カッターと後行カッターとの回転数 に差を与えた場合 $\left(f_{F} / f_{R}=0.33 \sim 3.0\right)$ の $S_{H}$ とカッター トルクとの関係を示すが, 両者の関係はカッタ一回転数 
に差のない場合と変わらない。これより, カッタートル クの特性について, $\mathrm{MF}$ シールドの先行カッターと後 行カッターは独立であると考えられる.

\section{（2）切羽安定性}

a ）地表面沈下

図一15に，軟地盤における各シールド型式の標準的 な横断方向地表面沈下分布を示す. 地表面沈下の絶対量 および横断方向の影響範囲は, 円形>横型 $M F>$ 縦型 $\mathrm{MF}$ となり, また縦型 $\mathrm{MF}$ シールドの上部先行型と下 部先行型との間に差がほとんどなかった。一方, 硬地盤 においては，地表面沈下はほとんど発生しなかった。

b ）地盤のゆるみ

掘進前後の地盤のコーン指数の低下状況を調べた結果 を図一16に示す.コーン指数の低下高さはいずれのシー ルド型式においても約 50 〜 $60 \mathrm{~cm}$ であるが, 低下の程 度は円形シールドに比べて MF シールドは小さい。ま た, 縦型 $M F$ シールドにおいて, 上部先行型と下部先 行型で周辺地盤のコーン指数の低下範囲を示すと, 図一

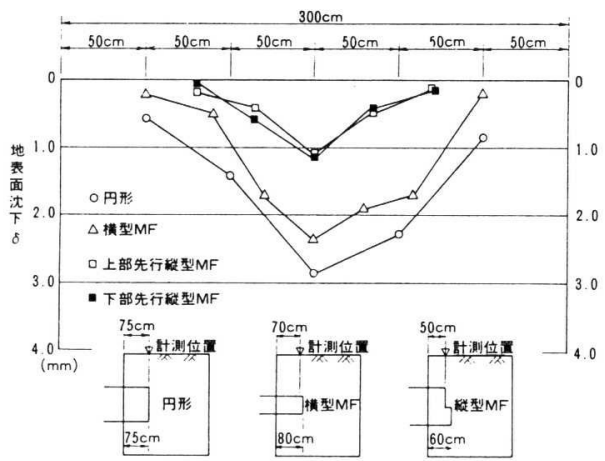

図一15 横断方向地表面沈下分布（軟地盤）
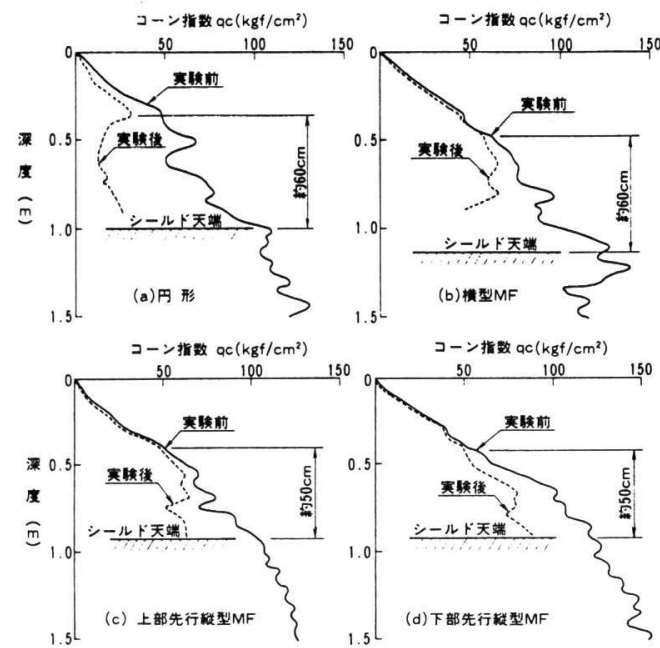

（测定位盛：掘湛ストローク中央部シールドセンター位冝）

図一16 実験前後のコーン指数の比較
17 となり，両者に大差は認められない。

さらに, $\mathrm{MF}$ シールドのくびれ部分付近の地盤の崩 壊の有無を調べるために, トレーサー（長さ $1 \mathrm{~cm}$ 程度 のゴムホース片) を $10 \mathrm{~cm}$ 間隔で設置した。その結果， 地盤条件, シールド型式，およびカッタ一回転方向にか かわらず，排出されたトレーサーはなく，くびれ部分付 近の地盤の崩壊はなかった。また, MF シールドにお ける排土量は, 軟地盤・硬地盤にかかわらず，掘進断面 積相当の排土量に等しかった.

これらの結果から，MF シールドの周辺地盤への影 響は円形シールドよりも少ないものと判断できる.

c)目視実験

地山崩壊の広がりや発生パターンを観察することを目 的として, 軟地盤において, 土被りを 0 とし, 積極的に 地山の崩壊を生じさせる掘進条件で実験を実施した。な お，土被りを有する通常の実験で用いた掘進条件 (0.2 $<V / f<1.0)$ では，いずれの MF シールドにおいても 地山の崩壊はなかった。そこで, 掘進速度 $V$ を 0.5 $1.0 \mathrm{~cm} / \mathrm{min}$, カッター回転数 $f$ を $9 \mathrm{rpm} と し$, カッター による地山の押し付けの程度がきわめて小さな掘進条件

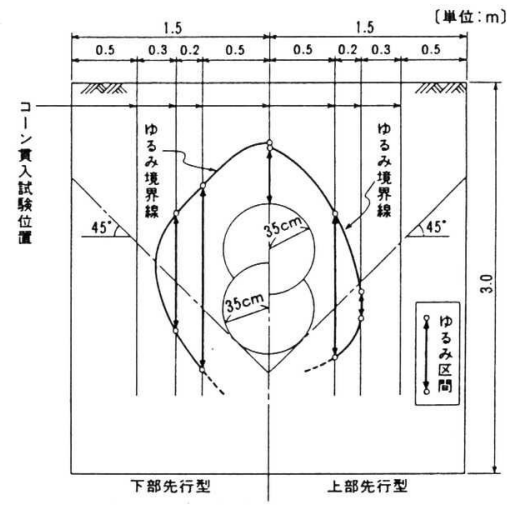

図一17 縦型 MF シールドのゆるみ比較

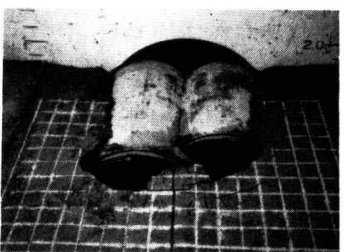

左 : 橿型MFシールト

(カッター回転方向 : 凤○) 左下: 嘴型M F シールド (上部先行型) 右下: 䋖型MFシールド (下部先行型) 〈格子の間晅は $10 \mathrm{~cm}$ >
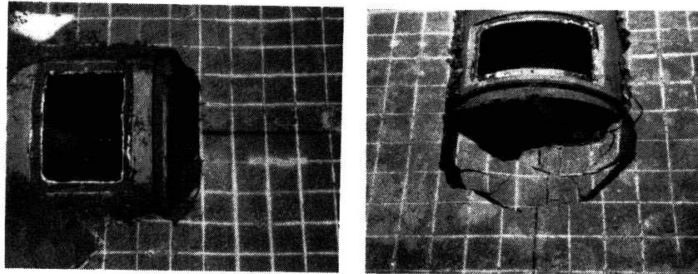

写真一1 目視実験状況 
$(V / f<0.1)$ で実験を行った. 横型 MF シールドおよ び縦型 MF シールドについて, 地山崩壊の主な観察結 果は下記のとおりである (写真一1参照).

・横型 MF シールド

カッター回転方向については, 逆回転 $(\bigcap 囚)$ は正回 転 (の囚)に比べて切羽が崩壊しにくかった。これは, 逆回転の場合, 先行部分亡後行部分との間のスキンプ レートが後行カッターの回転による土の引きずり込みに 対して屋根効果を発揮しているもののように観察され た. また, 正回転の崩壊パターンは, まず後行側で土砂 を引きずり込む方向に崩壊が生じ, しばらくした後, 先 行側に同様の崩壊が生じ，ゆるみが広がっていくという ものであった。なお，後行側のカッター回転数を少なく することにより，切羽の崩壊を起こりにくくできること がわかった。

・縦型 MF シールド（上部先行型）

上部カッターの前方 $15 \sim 20 \mathrm{~cm}$ 付近にクラックが現 われ,しばらく掘進した後に崩壊した.

崩壊領域の幅はカッター径の $70 \mathrm{~cm}$ 程度, 深さは上 部カッター下端までであり, 下部カッター下端からの大 きな崩壊は観察されなかった。これは下部カッターによ る地盤のゆるみが, 上部カッターの屋根効果により抑制 されたためと考えられる.

・縦型 MF シールド (下部先行型)

上部カッター前方 $15 \sim 20 \mathrm{~cm}$ と $25 \sim 30 \mathrm{~cm}$ の 2 か所 にクラックが発生し, まず前者の位置で下部カッタース キンプレートより上の部分が崩壊し, 次に後者の位置で 下部カッター下端からの大きな崩壊が生じた. 崩壊領域 の幅は, いずれも上部先行型と同様にカッター径程度で あった.

\section{（3）姿勢制御性}

\section{a) 要因の分類}

表一8 不つり合いモーメント算定 において考慮すべき要因

\begin{tabular}{|c|c|c|c|c|}
\hline 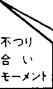 & 要 & $\begin{array}{l}\text { 䑫 } \\
\text { 型 } \\
M \\
\mathrm{~F}\end{array}$ & $\begin{array}{c}\text { 横 } \\
\frac{\text { 型 }}{M} \\
\mathrm{~F}\end{array}$ & 形 \\
\hline \multirow{3}{*}{$\begin{array}{ll}\exists & 1 \\
1 & 1 \\
1 & x \\
y & 2 \\
y & 1\end{array}$} & 周面缶 & $\Delta$ & 0 & $\bar{\Delta}$ \\
\hline & 面外面重 & $\Delta$ & 0 & $\Delta$ \\
\hline & 面内荷重 & 0 & 0 & 0 \\
\hline \multirow{4}{*}{ 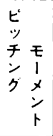 } & 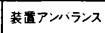 & $\square$ & $\square$ & $\square$ \\
\hline & 周面㙞 & 0 & $\Delta$ & $\triangle$ \\
\hline & 面外荷重 & 0 & $\Delta$ & $\Delta$ \\
\hline & 面内荷 重 & $x$ & 0 & $x$ \\
\hline \multirow{3}{*}{ 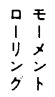 } & 面内荷重 & 0 & 0 & $x$ \\
\hline & カッタートルク & 0 & 0 & 0 \\
\hline & 措 倒 九 & $\Delta$ & $\Delta$ & $x$ \\
\hline
\end{tabular}

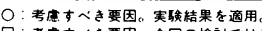

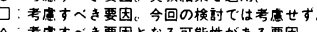
后すべぎ要因となる可能性がある要国。

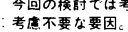

シールドの不つり合いモーメントは, ヨーイングモー メント $M_{y}$, ピッチングモーメント $M_{\rho}$, ローリングモー メント $M_{r}$ である.これらシールドの蛇行を支配する不 つり合いモーメントは, カッタートルク, カッターへの 作用力, 周面摩擦, シールドの自重などによって生ずる. 表一8は，不つり合いモーメント算定において考慮すべ き要因を整理したものである. 図一18に一例として上

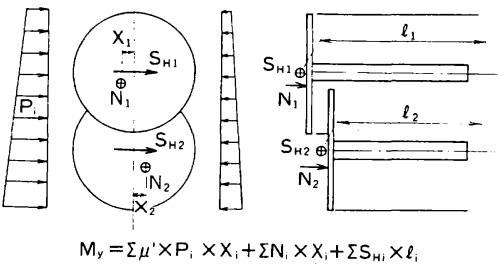

(a) ヨーイングモーメント $M_{y}$

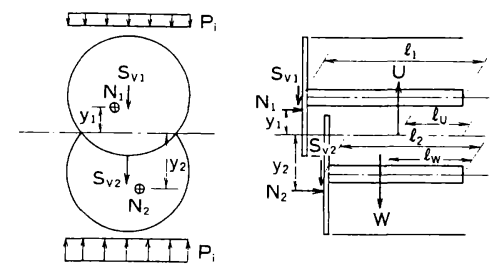

$M_{P}=W \times \ell_{w}-U \times \ell_{u}+\Sigma \mu^{\prime} \times P_{i} \times y_{i}+\sum N_{i} \times y_{i}+\sum S_{v i} \times \ell_{i}$

(b)ピッチンクモーメント $M_{p}$

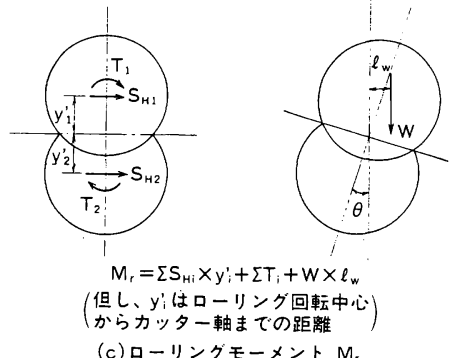

図一18 不つり合いモーメント要因分類（上部先行縦型 MF シールド)

表一9 機体に作用する不つり合いモーメント整理結果一覧表

\begin{tabular}{|c|c|c|c|c|c|c|c|}
\hline \multirow{2}{*}{\multicolumn{2}{|c|}{ 要 因 }} & \multirow{2}{*}{\multicolumn{2}{|c|}{ 円 }} & \multirow{2}{*}{ 形 } & \multirow{2}{*}{ 横 型 $M \quad F$} & \multirow[t]{2}{*}{ 轱 } & M \\
\hline & & & & & & & 下部先 行型 \\
\hline \multirow{4}{*}{$\begin{array}{l}\exists \\
1 \\
1 \\
1 \\
y \\
y \\
3 x \\
y \\
y \\
1\end{array}$} & (1)周面糜擦 & & & 0 & 49.7 & 0 & 0 \\
\hline & 々面外荷重 & & & 0 & $M_{y}=0.70\left|T_{f}\right|-1.58\left|T_{p}\right|+20.5$ & 0 & 0 \\
\hline & ３面内荷重 & & $n y=1.5$ & $7 \mathrm{Tc}$ & $M y=2.21 T_{F}+1.41 T_{R}$ & $M y=2.26 T_{r}+2.52 T_{R}$ & $M y=-1.30 T_{R}+2.26 T_{r}$ \\
\hline & $(11+i 2 \cdot+3)$ & & $h_{y}=1.5$ & $7 \mathrm{Tc}$ & $\begin{aligned} \mathrm{My}= & 0.70\left|\mathrm{~T}_{\mathrm{r}}\right|-1.58\left|\mathrm{~T}_{\mathrm{R}}\right| \\
& +2.21 \mathrm{~T}_{1}+1.41 \mathrm{~T}_{\mathrm{R}}+70.2\end{aligned}$ & $M y=2.26 T_{r}+2.52 T_{R}$ & $M y=-1.30 T_{R}+2.26 T_{r}$ \\
\hline \multirow{4}{*}{ 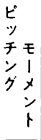 } & 4周面应擦 & & & 0 & 0 & 37.6 & -41.2 \\
\hline & ５面外荷雰 & & & 0 & 0 & $M p=1.3\left|T_{F}\right|-0.9\left|T_{n}\right|-20.2$ & $M p=1.8\left|T_{R}\right|-0.7\left|T_{r}\right|-13.5$ \\
\hline & 6 面内荷秉 & & & 0 & $M p=-0.33 T_{R}$ & 0 & 0 \\
\hline & $4+(5 ;+; 6)$ & & & 0 & $M p=-0.33 T_{R}$ & $M p=1.3\left|T_{F}\right|-0.9\left|T_{R}\right|+17.4$ & $M p=1.8\left|\mathrm{~T}_{\mathrm{R}}\right|-0.7\left|\mathrm{~T}_{\mathrm{f}}\right|-68.7$ \\
\hline \multirow{3}{*}{$\begin{array}{ll}a & z \\
1 & 1 \\
y & x \\
y & y \\
y & 1\end{array}$} & (7 面内水平力 & & & 0 & $\mathrm{Mr}=-0.09 \mathrm{~T}_{\mathrm{R}}$ & $\mathrm{Mr}=0.55 \mathrm{~T}_{\mathrm{f}}-0.72 \mathrm{~T}_{\mathrm{R}}$ & $\mathrm{Mr}=-0.37 \mathrm{TR}-0.55 \mathrm{Tr}$ \\
\hline & : & & $M_{r}=-T$ & & $M r=-T_{F}-T_{R}$ & $M r=-T_{F}-T_{R}$ & $M r=-T_{R}-T_{F}$ \\
\hline & $17+18$ & & $A_{r}=-T$ & & $M r=-T_{r}-1.09 T_{R}$ & $\mathrm{Mr}=-0.45 \mathrm{~T}_{\mathrm{r}}-1.72 \mathrm{~T}_{\mathrm{R}}$ & $\mathrm{Mr}=-1.37 \mathrm{~T}_{\mathrm{R}}-1.55 \mathrm{~T}_{\mathrm{r}}$ \\
\hline
\end{tabular}

c：四形かッタートルク，Tr：MF先行カッタートルク，TR：MF後行カッタートルク 面外荷重の合力の作用位蔫はカッター軸中心とした（实倹にて偏心量が少ない二とを確既） 
部先行縦型 MF シールドの不つり合いモーメントの計 算式を示す.

b) 不つり合いモーメント

表一9に, 各要因ごとに実験結果を整理して不つり合 いモーメントを負荷特性の代表值であるカッタートルク の関係式としてまとめたものを示す，ただし，シールド の自重による不つり合いモーメントは, 計算によって求 まるが，実際に用いられているシールドでは同一径の シールドでも異なる值をとり図一4の考え方が適用でき ないため, 実験の評価から除外した。この表の $T_{c}, T_{F}$, $T_{R}$ に, カッター回転方向による符号を考慮したカッター トルク（右回転を正，左回転を負）を代入することによ り, 各不つり合いモーメントの大きさおよび方向を求め ることができる.

\section{4. 考察}

実験結果から MF 指数を算定し, 負荷特性, 切羽安 定性, 姿勢制御性に関する MF シールドの特性を, 円 形シールドと比較して考察する.

\section{（1）負荷特性}

図一6に示したカッタートルクと $V / f$ の直線回帰式 から算定したカッタートルクに関する MF 指数を図一 19 に示す. $T_{M F}$ は，横型 $\mathrm{MF}$ シールドでは $0.31 \sim 0.46$, 縦型 MF シールドでは $0.18 \sim 0.29$ であり, $V / f$ が大 きくなるに従い増加するが，いずれも今回実験を行った $V / f$ の範囲でほぼ収束している，また，これらの值は シールド設計に用いられるトルク算定式 ${ }^{6)} T=\alpha D^{3}(\alpha$ : トルク係数, $D$ : シールド外径) を用いて以下のように 計算される $\mathrm{MF}$ 指数 $T_{M F}^{*}$ と比べて小さい.

$$
\begin{aligned}
T_{M F}^{*} & =\frac{M F \text { 先行カッタートルク }+\mathrm{MF} \text { 後行カッタートルク }}{\text { 円形カッタートルク }} \\
& =\frac{\alpha \times 0.7^{3}+\alpha \times 0.7^{3} \times 0.73}{\alpha \times 1.0^{3}} \\
& =0.59
\end{aligned}
$$

(0.73 はカッター軸回りの断面 1 次モーメントに 関する後行と先行の比)

総推進力 $F$ に関する MF 指数 $F_{M F}$ は, 図一 9 に示し た $F_{t}$ と $V / f$ の直線回帰式および表一 4 の $F_{f}$ を用いて

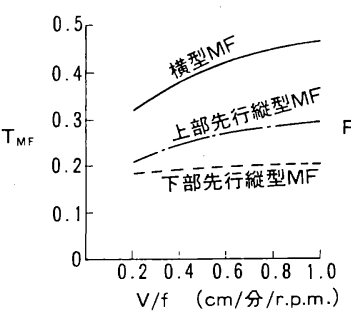

図一19 $T_{M F}$ と $V / f$ の関係

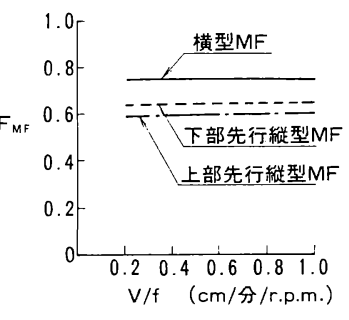

図一20 $F_{M F}$ と $V / f$ の関係
表一10 切羽安定性に関する MF 指数

\begin{tabular}{|l|l|l|l|}
\hline & 横型MF & $\begin{array}{c}\text { 上部先行 } \\
\text { 繸型M } F\end{array}$ & $\begin{array}{c}\text { 下部先行 } \\
\text { 縦型M F }\end{array}$ \\
\hline$\delta_{\text {max.MF }}$ & 0.82 & 0.37 & 0.40 \\
\hline$\delta_{A \cdot M F}$ & 0.69 & 0.21 & 0.22 \\
\hline$h_{M F}$ & 1.00 & 0.83 & 0.83 \\
\hline
\end{tabular}

算定した (図一20). $F_{M F}$ は, 横型 $\mathrm{MF}$ シールドでは 0.75 , 縦型 MF シールドでは上部先行型で $0.59 \sim 0.61$, 下部 先行型で $0.64 \sim 0.65$ である.

ところで，実際に用いられているシールドにおいて， 掘削断面積当たりの総推進力はほぼ一定值であり ${ }^{6)}, こ$ の関係を用いて求まる MF 指数 $F_{M F}^{*}$ は, MF シールド と円形シールドの掘削断面積の比 0.86 となり, 実験に よる $F_{M F}$ の方が小さい.

\section{（2）切羽安定性}

切羽安定性の MF 指数として, 図一 15 に示した横断 方向地表面沈下分布より求めた地表面最大沈下量に関す る MF 指数 $\delta_{\max \cdot M F}$, 横断面方向の沈下面積に関する MF 指数 $\delta_{A \cdot M F}$, また, 図一16 より求めたコーン指数の 低下高さに関する $\mathrm{MF}$ 指数 $h_{M F}$ を表一10に示す.なお, $\delta_{A \cdot M F}$ は図一15において土槽壁面（シールドセンターか ら左右 $1.5 \mathrm{~m}$ の位置) で沈下量が 0 として求めたもの である.

$\delta_{\max \cdot M F}, \delta_{A \cdot M F}, h_{M F}$ はシールド型式にかかわらずいず れも 1.0 以下であり, MF シールドの切羽安定性は円 形シールドより優れている.

また, 縦型 MF シールドのこれらの MF 指数は, 上 部先行型と下部先行型で大差はなく, 横型 MF シール ドよりも小さい. さらに，目視実験で観察された切羽の 崩壊幅は, いずれの型式においてもシールド幅に等し かった.これらのことより, シールド高さに比べてシー ルド幅が切羽安定性に大きな影響を与えると考えられ る.

\section{（3）姿勢制御性}

表一9の $T_{C}, T_{F}, T_{R}$ に図一7，8 のカッタートルクと $V / f$ の直線回帰式を代入して求めたヨーイングモーメ ント $M_{y}$ に関する MF 指数 $M_{y_{w r}}$ およびローリングモー メント $M_{r}$ に関する MF 指数 $M_{r_{u r}}$ を図一21，22 に示す. なお， $M_{y}$ および $M_{r}$ は正または負となるが， $M_{y_{w r}}, M_{r_{w r}}$ は絶対值で評価した. また, これらの図は, 先行カッター と後行カッターの回転数が同一の場合の MF 指数を示 したものである.

$M_{y_{w r}}$ は, $V / f$ に依存しており, また, 同一のシール ド型式でもカッターの回転方向により值が異なるが，そ の最大值は実験範囲 $(0.2<V / f<1.0)$ において, 横 型 MF シールド 0.71 , 縦型 MF シールドでは上部先行 
型 0.46 ，下部先行型 0.28 である。これらの值はいずれ も 1.0 より小さく, MF シールドのヨーイングモーメ ントは円形シールドよりも小さい.

$M_{r_{u r}}$ の最大值は, 実験範囲において横型 MF シール ド 0.49 , 縦型 MF シールドでは, 上部先行型 0.40 , 下 部先行型 0.30 であり，いずれも 1.0 より小さい.また, 同一のシールド型式における $M_{r_{u s}}$ は, 先行と後行のカッ ターが同方向に回転する方が大きい.

ピッチングモーメント $M_{\rho}$ については, 円形シールド の $M_{p}$ が 0 (シールドの自重による不つり合いモーメン 卜を実験対象外としている）のため MF 指数を算定で きない，しかし，MF シールドの $M_{p}$ は，図一23に示す ようにいずれのシールド型式においても円形シールドの $M_{y}$ よりはるかに小さな値である.

以上のことは, 先行カッターと後行カッターの回転数 が同一の場合に対して，不つり合いモーメントに関する MF 指数などを示したものである.ここで, 先行カッター 之後行カッターの回転数に差を与えた場合, さらに縦型 MF シールドでは上部カッタートルクを前述の方法で 補正した場合も含めて, 各不つり合いモーメントがどの ような範囲をとり得るのかを以下のように求めてみた. 表一9 の式の $T_{F}$ と $T_{R}$ は実験結果から独立に取り扱う ことができるものとし，また，カッタートルクを実験結 果に基づき，下記のような範囲とした。

円形シールドカッター $: 125 \leqq T_{c} \leqq 250(\mathrm{kgf} \cdot \mathrm{m})$

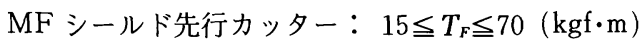

$\mathrm{MF}$ シールド後行カッター： $5 \leqq T_{R} \leqq 50(\mathrm{kgf} \cdot \mathrm{m})$

計算結果を図一24に示す. MF シールドの $M_{y}$ および $M_{r}$ の方向と大きさは, シールドの型式にかかわらずカッ ターの回転方向により異なり広範囲な值をとり得ること

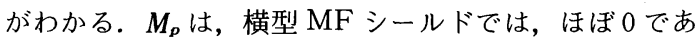

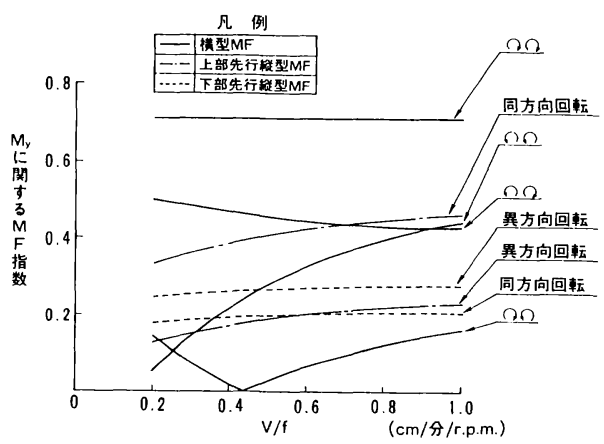

图一21 $M_{y}$ に関する MF 指数

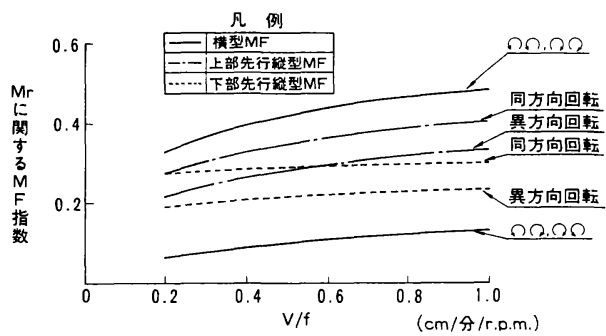

图一22 $M_{r}$ に関する MF 指数

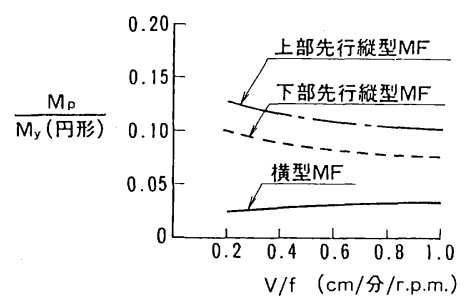

図一23 $M_{\rho} / M_{y}($ 円形 $)$ と $V / f$ の関係

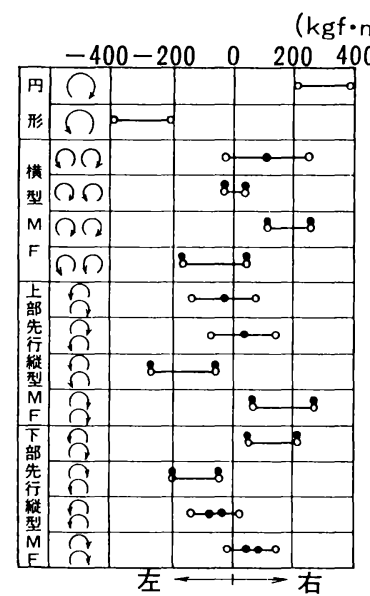

(a) $M_{y}$

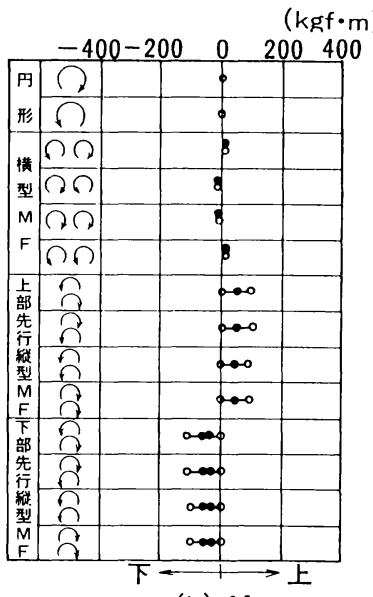

(b) $M_{p}$

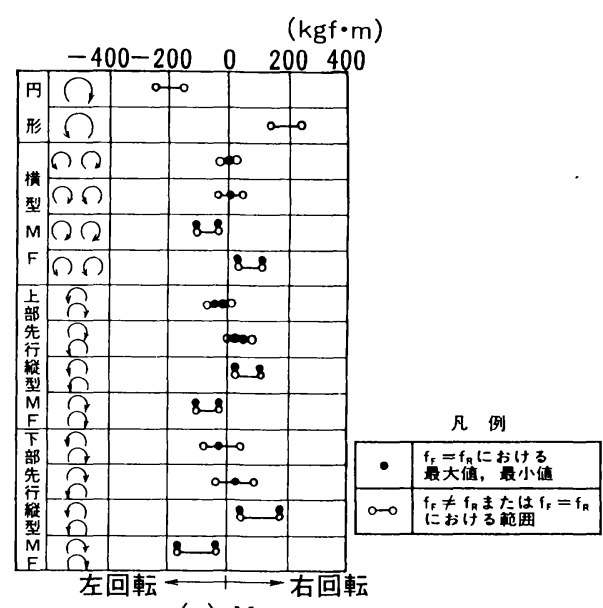

(c) $M_{r}$

図一24 不つり合いモーメントの計算結果 
り, 縦型 MF シールドでは上部先行型が上方向, 下部 先行型が下方向となっているが, カッターの回転数に差 を与えることにより小さくできることがわかる.

これらのことより, MF シールドの不つり合いモー メントの方向と大きさは, カッターの回転方向や回転数 を選択することにより制御できる，たとえば，直線区内 では不つり合いモーメントの小さな状態で，また曲線区 内では， $M_{y}$ をその方向を考えて発生できるなど， MF シールドは円形シールドより掘削性に優れていると考え られる.

\section{5. まと め}

$\mathrm{MF}$ シールドの掘削特性を解明する目的で, 複線鉄 道用のシールドを対象として横型および縦型の MF シールドについて円形シールドとの比較模型実験を実施 した. 本実験条件のもとで得られた MF シールドの負 荷特性, 切羽安定性, 姿勢制御性に関する実験の結論を MF 指数（円形シールドに対する MF シールドの比） を用いて要約すると次のようになる。

（1） カッタートルクに関する MF 指数 $T_{M F}$ は横型 $\mathrm{MF}$ シールドで $0.31 \sim 0.46$, 縦型 $\mathrm{MF}$ シールドで 0.18 〜0.29であった.これらの值は現行の設計法 ${ }^{6}$ における トルク算定式 $T=\alpha D^{3}$ ( $\alpha$ : 係数, $D:$ シールド外径) をおのおののカッターに適用して計算される MF 指数 $T_{M F}^{*} 0.59$ に比べ小さかった.

総推進力に関する $\mathrm{MF}$ 指数 $F_{M F}$ は横型 $\mathrm{MF}$ シールド で 0.75 , 縦型 $\mathrm{MF}$ シールドで 0.59 〜 0.65 であった. これらの值も単位掘削断面積当たりの総推進力が等しい ものとして計算される $\mathrm{MF}$ 指数 $F_{M F}^{*} 0.86$ に比べ小さ かった.

これらのことより, MF シールドの負荷特性は円形 シールドよりも有利と判断できる.

（2）地表面最大沈下量に関する MF 指数 $\delta_{\max \cdot M F}$ は 横型 MF シールドで 0.82 , 縦型 MF シールドで 0.37 〜0.40であった. また，横断方向の沈下面積に関する $\mathrm{MF}$ 指数 $\delta_{A \cdot M F}$ は横型 MF シールドで 0.69 , 縦型 MF シールドで $0.21 \sim 0.22$ であり，いずれも円形シールド に比べて小さく, MF シールドの切羽安定性は高いも のと判断できる.

（3） MF シールドのヨーイングモーメント，ロー リングモーメントに関する MF 指数はカッターの回転
数および回転方向の組合せにより種々の值となるが，同 一回転数のものに限定すれば, ヨーイングモーメントに 関する MF 指数 $\boldsymbol{M}_{\boldsymbol{y}_{\boldsymbol{y}}}$ の最大值は横型 MF シールドで 0.71 , 縦型 MF シールドで 0.46 , ローリングモーメン 卜に関する MF 指数 $\boldsymbol{M}_{r_{w F}}$ の最大值は横型 MF シールド で 0.49 , 縦型 MF シールドで 0.40 といずれも円形シー ルドに比べ小さかった.

また， MF シールドのピッチングモーメント $M_{\rho}$ は円 形シールドのヨーイングモーメント $M_{y}$ の $0.03 \sim 0.13$ と小さな值であった.

これらのことより，MF シールドの姿勢制御性は円 形シールドより優れていると判断できる.

以上のとおり, 本実験の結果, $\mathrm{MF}$ シールドの設計・ 施工上において重要である掘削特性の多くが明らかに なった。

本研究にあたり, 東京大学 西松裕一教授をはじめ多 くの方々にご指導・ご協力をいただいた。ここに深く謝 意を表す次第である.

\section{参 考 文 献}

1) 松本嘉司：多円形断面シールドトンネル工法 (MFS工 法）の開発, 日本機械学会誌, 第 19 巻, 第 839 号, pp. 84 88, 1988. 10.

2）松本嘉司 - 岡田 宏 - 内田聰吉 · 大塚本夫：多円形断面 シールドトンネル (MFS) 工法の研究および開発, 土木 学会論文集, 第 397 号 $/ \mathrm{N}-9$, pp. 17 26, 1988. 9.

3）松本嘉司・新井時夫 - 大田 弘・波多腰明 - 大石善啓 : 多円形断面シールド (MF シールド) の模型実験その 1 , 土木学会第 43 回年次学術講演会講演概要集 III, pp. 954 $\sim 955,1988.10$.

4) 松本嘉司・新井時夫 - 岸 研司 - 喜多信仁 - 波多腰明 : 多円形断面シールド（MF シールド）の模型実験その 2, 土木学会第 43 回年次学術講演会講演概要集 III, pp. 956 〜957, 1988. 10.

5）石崎英夫 - 榎島幸博 - 大田 弘 -千葉 章 - 岸 研司 喜多信仁：縦型マルチフェイスシールドの切羽安定数值 解析例, 土木学会第 43 回年次学術講演会講演概要集 III, pp. 986 987, 1988. 10.

6) 土木学会：トンネル標準示方書 (シールド編) ・ 同解説, 1986.6.

(1989.2.6 • 受付） 